\title{
THE EFFECTS OF ADSORBENT MATERIALS ON THE LIPID QUALITY OF LEMURU FISH OIL AND THE ENRICHMENT OF OMEGA-3 USING LIPASE
}

\author{
[Pengaruh Material Adsorben terhadap Kualitas Lipida Minyak Ikan Lemuru dan \\ Pengayaan Omega-3 Menggunakan Lipase]
}

\author{
Raden Tina Rosmalina*, Wawan Kosasih, and Sri Priatni \\ Research Unit for Clean Technology, Indonesian Institute of Sciences (LIPI), Bandung
}

Received May $8^{\text {th }} 2020 /$ Accepted April $7^{\text {th }} 2021$

\begin{abstract}
Sardinella (lemuru) is a genus of fish that is widespread in the East Java Sea region, especially in Muncar, Banyuwangi in East Java Province, Indonesia. Marine fishes are rich in essential fatty acids, including omega-3. This study aims to improve the quality of lemuru fish oil through the use of adsorbent materials such as bentonite and activated carbon. The sample was analyzed to determine its free fatty acid (FFA) content and peroxide value (PV) using the titrimetric method. The clarity of the oil was determined using the spectrophotometric method $(\lambda 440 \mathrm{~nm})$. The omega 3 content from the fish oil sample was then enriched through enzymatic reactions using lipase. Enzymatic reactions were carried out for 5, 10, 15, 20, 35 , and 47 hours with a lipase concentration of 500, 1000, 1500, and 2000 units respectively. The omega3 content of the fish oil products was analyzed using the GC-FID method. The results show that the addition of $3 \%$ activated carbon and bentonite in the fish oil reduced the FFA and PV results. Moreover, the absorbance value at $\lambda 440 \mathrm{~nm}$ was also reduced from 0.883 to 0.559 . The highest content of omega-3 was obtained through hydrolysis with lipase at a concentration of 1000 units for 35 hours with alpha-methyl linolenate (ALA), methyl all-cis-5,8,11,14,17-eicosapentanoate (EPA) and cis-4,7,10,13,16,19-docosahexaenoic acid methyl ester (DHA) at $0.78,1.06$, and $0.29 \%$ respectively.
\end{abstract}

Keywords: activated carbon, adsorbent, bentonite, lemuru fish oil, purification

\begin{abstract}
ABSTRAK
Ikan sardinella (lemuru) adalah salah satu jenis ikan yang tersebar luas di wilayah Laut Jawa Timur, terutama di Muncar, Banyuwangi, Provinsi Jawa Timur, Indonesia. Ikan laut kaya akan asam lemak esensial seperti omega-3. Penelitian ini bertujuan untuk meningkatkan kualitas minyak ikan lemuru dengan menggunakan bahan adsorben berupa bentonit dan karbon aktif. Minyak ikan lemuru dimurnikan dengan bentonit dan karbon aktif. Sampel minyak ikan kemudian ditentukan nilai asam lemak bebas dan angka peroksidanya dengan metode titrimetri, sedangkan kejernihan minyak ditentukan dengan metode spektrofotometri pada $\lambda 440 \mathrm{~nm}$. Kandungan omega-3 minyak ikan diperkaya melalui reaksi enzimatis menggunakan enzim lipase komersial. Reaksi enzimatis dilakukan selama 5, 10, 15, 20, 35, dan 47 jam dan konsentrasi enzim lipase berturut-turut 500, 1000, 1500, dan 2000 unit. Kandungan omega-3 dari produk minyak ikan dianalisis menggunakan kromatografi gas dengan detektor FID. Hasil penelitian menunjukkan bahwa penambahan 3\% karbon aktif dan 3\% bentonit pada minyak ikan dapat menurunkan nilai angka peroksida dan asam lemak bebas. Selain itu nilai absorbansi pada $\lambda 440 \mathrm{~nm}$ juga berkurang dari 0,883 menjadi 0,559. Kadar omega-3 tertinggi diperoleh melalui hidrolisis dengan lipase pada konsentrasi 1000 unit selama 35 jam dengan kadar alpha-methyl linolenate $(A L A)$, methyl all-cis5,8,11,14,17-eicosapentanoate (EPA), dan cis-4,7,10,13,16,19-docosahexaenoic acid methyl ester (DHA) masing-masing sebesar 0,78; 1,06; dan 0,29\%.
\end{abstract}

Kata kunci: bentonit, karbon aktif, minyak ikan lemuru, pemurnian, reaksi enzimatis

\footnotetext{
The manuscript has been presented in The $16^{\text {th }}$ Asean Food Conference 2019, October $15^{\text {th }}-18^{\text {th }} 2019$, Bali-Indonesia *Corresponding Author: E-mail: raden.tina.rosmalina@lipi.go.id
} 


\section{INTRODUCTION}

Fatty acids and fish oil have become a prominent area of interest because of omega-3 (Hong et al., 2015). Fish oil originates from the oilrich fish tissue that contains omega-3 fatty acids (Abu-Ouf and Jan, 2014). The dominant types of omega-3 in fish oil are EPA and DHA (Suriani et al., 2019; Aryani et al., 2017). Previously, fish oil was a product of the fish meal used for animal feed. This is now recognized as the primary source of these fatty acids (Bonilla and Concha, 2018). Among the sources in the human diet, fish has been highly regarded as an easy access yet highly nutritious food due to its high protein content and the presence of polyunsaturated fatty acids (PUFA), particularly, omega-3 fatty acid, eicosapentaenoic acid and docosahexaenoic acid (Panagan et al., 2012; Raharja, 2012; Bija et al., 2016; Ahmed et al., 2017; Akbar et al., 2017; Maki et al., 2017; Srigley and Rader, 2014; Moharana et al., 2016; Eltweri et al., 2017; Yang et al., 2020). Raw marine fish oil extracts also contain five new arsenolipids (Pereira et al., 2016). The remarkable impact of omega-3 fatty acids is closely linked with healthy aging, as well as other substantial health effects (Kolanowski, 2010). Other potencies include the omega-3 fatty acid potential to exhibit pleiotropic cardiometabolic effects via multiple actions (Kromhout, 2012), contributing to gestational diabetes mellitus effects (Ostadrahimi et al., 2016) and preventing cardiovascular disease and cancer (Billman and Harris, 2011; Mozaffarian and Wu, 2011; Schuchardt et al., 2011; Wen et al., 2014; Dinicolantonio et al., 2014; Mori, 2014; Calvo et al., 2017; Hu et al., 2019; Manson et al., 2018; Fonda et al., 2016; Minihane, 2013; Pirillo and Catapano, 2013; Siscovick et al., 2017; Stephenson et al., 2013; Mohebi and Bikdeli, 2014; Yinko et al., 2014; Nestel et al., 2015; Endo and Arita, 2016; Harris et al., 2018; Jump et al., 2012; Ferrari et al., 2020; Lombardi et al., 2021; Jo et al., 2021; Elagizi et al., 2021; Weinberg et al., 2021).

The addition of fish oil can cause problems, specifically in terms of the odor and taste of most food products. The odor and taste of fish oil is what consumers dislike the most. However, modern processing technology can reduce these problems through purification techniques. The free fatty acids can be removed through deacidification (neutralization), while the color and oxidation can be removed through bleaching. The flavor can be removed through the process of deodorization, The PUFA concentration is increased through winterization and/or molecular distillation, and oxidation can be prevented by adding antioxidants. Bleaching is a noteworthy method in oil refinement (Monte et al., 2015; Kralovec et al., 2012). Color properties have a significant effect on consumer acceptability, especially edible products, beside its nutritional value and sensory properties. Upon the consumer's consideration, the color of the food directly shows its quality and maturity (for fruits and vegetables), which links to the customer expectations, their like or dislike of it according to their preference, and its acceptability. The color of the product is also an important consideration among technologists. The color properties indirectly show the consistency, stability and composition of the product, which also lead to solving the presented problem by enhancing its appeal and appearance to meet the customer needs (Francis, 1999).

The oil purification process is beneficial as it removes impurities, lowers the free fatty acid content, and clears the oil color. Bleaching is the process used to refine the oil color because fish oil derived from waste tends to not look appealing. It needs to be refined through bleaching, which utilizes adsorbent.

Unrefined fish oil is still used as an animal feed ingredient in Indonesia. It contains soap stock, and high primary and secondary lipid oxidation product content which have been the problems associated with color, odor, flavor, and other impurities. Fish oil refining and purification through an effective and efficient method is very important for improving the quality of fish oil that is suitable for consumption.

An adsorbent can adsorb the impurities of the components, pigments, and free fatty acids in the fish oil. Adsorbents, which are potentially used in purification process, include activated carbon, attapulgite, bentonite, and chitosan (Suseno et al., 2013). The amount of adsorbent used in the bleaching process varies depending on the type of oil, the intensity of the oil color, and the desired color of the bleached oil (García-Moreno et al., 2013). Adsorbent refining is a common technique used to enhance the quality of edible oil. Adsorbents are usually used in the bleaching process to remove the color pigment, which is an undesirable compound in the oil (Ketaren, 2012).

The main types of pelagic fish are lemuru fish, which are commonly found in the waters of the Bali Strait (Dari et al., 2017). Sardine fish or lemuru fish are one of the potential sources of a high level of lipids that contain the crucial EPA and DHA. Sardine fish processing waste includes the liver, head, and intestines. The results of the analysis of oil extraction from the processing of these ingredients indicates that there is an essential PUFA content (Kones and Rumana, 2017).

The lemuru fish treatment by product characteristic is that it exhibits a fluctuating amount of saturated fatty acids. According to the previous study, the treatment uses a variety of bleach components such as $5 \%$ activated charcoal and zeolite, and $5 \%$ bentonite (Saraswati, 2013). A bentonite 
concentration of $5 \%$ is effective for improving the physical and chemical quality of rice bran oil. The bleaching process utilizes $25 \% \mathrm{HCl}$ activated zeolite. The bleaching material, in the form of clay, is activated at $90^{\circ} \mathrm{C}$ at $5 \%$ of the weight of oil for 60 min (García-Moreno et al., 2013). This process is able to improve the quality of the fish oil by products following the lemuru milling process.

On an industrial scale, conventional oil purification processes are usually carried out through several different chemical methods including the process of separating the phospholipids through a degumming process using a $5 \%$ magnesol $\mathrm{XL}$ adsorbent (Haryati et al., 2017), deacidification using conventional solvent extraction and membrane deacidification, the bleaching process in various conditions (Charanyaa et al., 2017), and the addition of odor removal agents to reduce the compounds that cause the odor. However, there are some weaknesses regarding these processes including the occurrence of environmental pollution due to the use of alkali chemicals and the loss of some neutral oil. To eliminate the volatile compounds and free fatty acids in the physical purification of the oil, an alternative method is proposed by applying hightemperature steam at a low pressure. However, in practice, this process still requires an initial refining process that uses chemicals. This is not suitable for oils that are vulnerable to high temperatures such as fish oil (Čmolík and Pokorný, 2000). To remove contaminants in fish oil such as dioxins and PCBs, recently the use of activated carbon has been proposed, involving a physical adsorption process (Maes et al., 2005). The odor of raw fish oil is highly disturbing and limits its application in the food industry. Thus, the process of removing the odor becomes an important step. Deodorizing traditional oils can be done by heating them at high temperatures. In this study, fish oil refinement was carried out using a combination of two adsorbents, specifically activated carbon and bentonite.

In this study, the purification of fish oil was carried out using carbon black and bentonite as trial adsorbents because they are easy to find in daily life compared with another adsorbent, magnesol XL. In this study, it is expected that we will be able to determine the right type of adsorbent and concentration to improve the quality of lemuru fish oil. This study aims to improve the quality of lemuru fish oil through adsorption by decreasing the amount of free fatty acids (FFAs) to reduce oxidation. Oxidized products can cause rancidity in fish oil. Decreasing the peroxide value (PV) avoids damage to the fish oil and removes the foul odor from the oil. The clarity of the fish oil goes slightly yellow, enriching the omega-3 content through an enzymatic reaction using lipase.

\section{MATERIALS AND METHODS}

\section{Materials}

The materials used in this study included lypase enzyme powder $(200,000$ unit/g) purchased from Xi'an Lyphar Biotech Company (Shaanxi, China). The phosphate buffer, boron trifluoride (BF3), ethanol, $\mathrm{KOH}$, phenolphthalein, sodium thiosulfate, acetic acid, chloroform, methanol, potassium iodide, and n-hexane (Merck, USA). The omega-3 standard, alpha-methyl linolenate (ALA) (Merck, USA) and methyl all-cis-5,8,11,14,17-eicosapentanoate (EPA), and cis-4,7,10,13,16,19-docosahexaenoic acid methyl ester (DHA) (Sigma Aldrich, USA).

\section{The absorption treatments of the lemuru fish oil}

The sample used in this study was lemuru fish oil from a local fish processing unit manufacturer, CV. Biji Sesawi (Banyuwangi, East Java Provinces, Indonesia). The lemuru fish oil was placed in a container and stored for about $10-30$ day at $4^{\circ} \mathrm{C}$. The absorption treatments of the lemuru fish oil were based on the research by Nadia et al. (2020) and Ayu et al. (2020) with some modifications. The lemuru fish oil was prepared in $100 \mathrm{~mL}$ volumes for each treatment. The treatments were carried out by adding 1,2 , and $3 \%$ activated carbon or bentonite as the adsorbent with 2 replications before being heated at $800^{\circ} \mathrm{C}$ for 30 minutes. The lemuru fish oil samples were then stirred at room temperature and centrifuged at $6000 \mathrm{rpm}$ for 10 minutes. The first layer was put into a vial for further analysis.

\section{Determination of free fatty acids (FFAs) (AOAC, 2005)}

Lemuru fish oil $(10 \mathrm{~g})$ was added to $50 \mathrm{~mL}$ of $95 \%$ ethanol and boiled for 10 minutes. Two drops of $2 \%$ phenolphthalein were added to mixture and then titrated with $\mathrm{KOH} 0.1 \mathrm{~N}$ until a pink color appeared. FFA was expressed as a percentage of $0.862 \%$. This stage of the analysis was replicated twice for each bentonite concentration. The results of the FFA analysis obtained a result of $(0.862 \pm$ $0.021) \%$.

\section{Determination of the peroxide value (PV) (AOAC, 2005)}

The lemuru fish oil $(5 \mathrm{~g})$ was put into a $250 \mathrm{~mL}$ Erlenmeyer flask. A volume of $30 \mathrm{~mL}$ of a mixture of acetic acid and chloroform was added with a ratio of $3: 2$, and then $0.5 \mathrm{~mL}$ of potassium iodide was added and the solution was mixed before the addition of 30 $\mathrm{mL}$ of distilled water. The solution was titrated with $0.01 \mathrm{~N}$ sodium thiosulfate until it turned yellow. Subsequently, $0.5 \mathrm{~mL}$ of $1 \%$ indicator starch solution was added until a blue color appeared in the solution. The titration process was continued by shaking the solution until the color of the solution 
turned light blue, indicating the release of iodine from the chloroform layer. Titration was performed until the disappearance of the blue color from the solution. The PV was expressed as meq $/ \mathrm{Kg}$. This stage of the analysis was replicated twice for each activated carbon concentration. The results of the FFA analysis obtained a value of $0 \mathrm{meq} / \mathrm{Kg}$.

\section{Enzymatic hydrolysis of the fish oil}

The omega- 3 content of the treated fish oil was enriched through an enzymatic reaction using lipases. Briefly, the lemuru fish oil $(0.6 \mathrm{~g})$ was mixed with $1.3 \mathrm{~mL}$ hexane, lipase $(1000 \mathrm{u} / \mathrm{mL})$ and $0.1 \mathrm{M}$ phosphate buffer pH 5.7 until $3 \mathrm{~mL}$ total volume was reached. The solution was incubated at room temperature and shaken at $150 \mathrm{rpm}$. The reaction was ended through the addition of $2 \mathrm{~mL}$ methanol. The enzymatic hydrolysis was performed at 5,10 , $15,20,35$, and 47 hours.

\section{Preparation of the omega-3 standard solution and methylation (AOAC, 2005)}

The stock solutions of ALA, EPA and DHA were prepared by dissolving each substance in hexane at $50 \mathrm{mg} / \mathrm{mL}$. The solutions were subsequently stirred to prepare the mixture of standard solution at a concentration of $5000 \mu \mathrm{g} / \mathrm{mL}$. For the linearity determination, the standard mixture solution was diluted to a concentration range of 250 to $2000 \mu \mathrm{g} / \mathrm{mL}$ in hexane. For the methylation, the fish oil $(0.125 \mathrm{~g})$ was placed in a flask followed by the addition of 0.5 $\mathrm{mL} \mathrm{BF} 3$ in $\mathrm{MeOH}$ (14\%). BF3 was used due to a better chromatographic outcome in a preliminary experiment compared to other solvents such as potassium hydroxide and sodium methoxide. The flask containing the fish oil and $\mathrm{BF}_{3}$ was incubated in an incubator shaker at $55^{\circ} \mathrm{C}$ for 1.5 hours. Afterwards, $0.5 \mathrm{~mL}$ saturated $\mathrm{NaCHO}_{3}$ and $1.0 \mathrm{~mL}$ hexane were added to the flask. The mixture was mixed and shaken well using a vortex for 30 seconds. The mixture was placed in a freezer for 10 min to obtain a two-layer formation. A volume of 0.5 $\mathrm{mL}$ hexane from the upper layer was carefully transferred into a vial for gas chromatography $(G C)$ analysis.

\section{Omega-3 fatty acid analysis (AOAC, 2005)}

The fatty acid composition of the fish hydrolysate samples was analyzed using GC Agilent 7890B (Agilent Technologies Inc., Santa Clara, USA) equipped with a split injector and a flame ionization detection (FID) system in order to quantify each fatty acid methyl ester (FAME) component. The FAMEs were separated using the HP-5 column instrument $(30 \mathrm{mx0} 0.32 \mathrm{~mm}$ i.d, $0.25 \mu \mathrm{m})$. The oven temperature was held stable at $100^{\circ} \mathrm{C}$ for 2 minutes and increased to $240^{\circ} \mathrm{C}$ at $10^{\circ} \mathrm{C} /$ minutes, then held for 1 minutes. The temperatures of the detector and injector were kept at 300 and $250^{\circ} \mathrm{C}$ respectively. The sample $(1 \mu \mathrm{L})$ was injected with a split ratio of $100: 1$. The carrier gas used by the system was helium amounting to $3.0 \mathrm{~mL} /$ minutes and controlled at 15.726 psi. The hydrogen and air used by the FID were maintained at 30 and $400 \mathrm{~mL} /$ minutes respectively. All omega-3 peaks were identified based on their retention time according to the correspondding standards. The omega-3 concentration was determined by plotting the peak area against the calibration curve of each compound (ALA, EPA and DHA). The omega- 3 fatty acid concentration was expressed as ppm. The analysis was replicated twice. The following results of the FFA analysis were obtained: $(869.58 \pm 0.721)$ ppm or $(0.870 \pm 0.00007) \%$.

\section{RESULTS AND DISCUSSION}

\section{Free fatty acids (FFAs)}

The less attractive taste in oil is related to the content of FFAs. The value of the FFAs in the fish oil processing industry is primarily determined by the amount of alkali used in the refining process. FFAs are an indication of the hydrolytic rancidity of the FFA levels determined by standard alkaline titration (Azman et al., 2018). FFAs are a product of the triacylglyceride hydrolysis reaction and are closely related to the storage process (Nurjanah et al., 2014). Factors that can affect the value of free fatty acids include poor storage, which can increase the fatty acid levels. Fatty acid oxidation is highly dependent on the number of double bonds and is influenced by temperature, oxygen concentration, metals, water activity, prooxidants, antioxidants, and catalysts. PUFA components, which are mostly found in fish oil, have a number of long double bonds that are easily oxidized compared to black seed oil, which is composed of mono-unsaturated fatty acids. The increase in the value of the FFAs in the oil can increase oxidation. An oxidized product can result in the rancidity of the aforementioned oil. Ghani (2014) reported that adsorbents function as a substance used to absorb the components of the FFAs within the oil without hydrolyzing the oil itself. The results of the FFA test are presented in Figure 1.

The FFAs were evaluated by comparing the lemuru fish oil without and with the addition of 1,2 and $3 \%$ activated carbon or bentonite. The FFA testing varied between 0.862 and $1.2098 \%$, which showed a high accuracy compared to the FFA testing of $1.68 \%$ found in the previous study (Nadia et al., 2020). The standard deviation was between 0.021 and $0.043 \%$. The limit required for the FFAs by the International Fish Oil Standard (IFOS) 2014 is FFA $\leq 1.5 \%$ (IFOS, 2014). An FFA-focused study of lemuru fish oil can indicate the tolerance values 
within the allowable limit. Figure 1 demonstrates that bentonite results in a more effective reduction of FFAs than activated carbon. This is because the ability of the activated carbon to adsorb FFAs is smaller than that of bentonite. The smaller adsorption ability is probably due to the larger size of the activated carbon particles compared to bentonite. One of the factors that influences adsorption is the size of the adsorbent particles. The smaller the particle size, the greater the diffusion rate of the solute molecules into the adsorbent pores (Rio et al., 2009). The activated carbon particles are granular, whereas bentonite particles are powder.

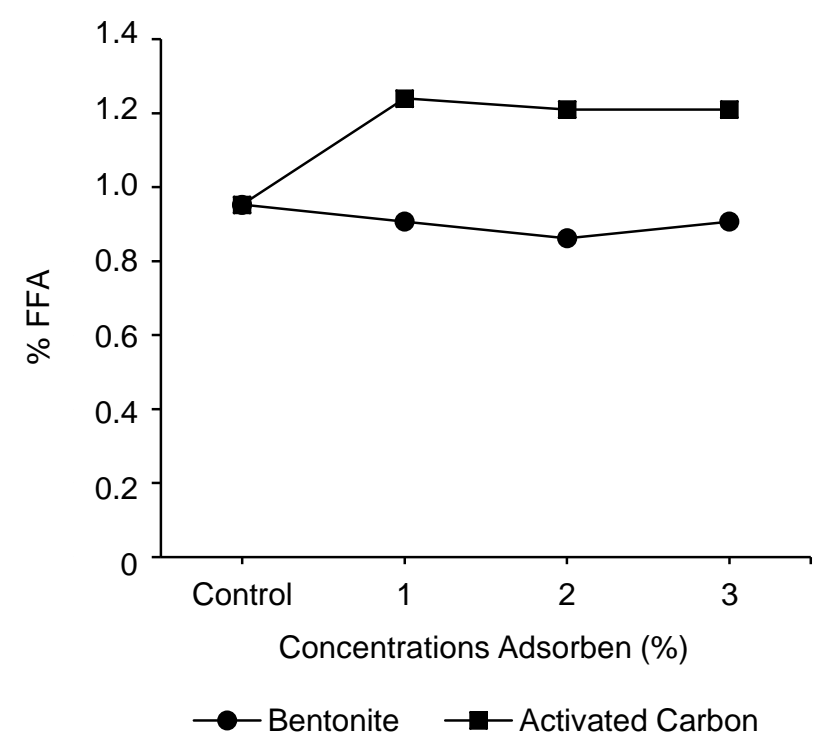

Figure 1. The FFA of the lemuru fish oil treated with bentonite and activated carbon

\section{Peroxide value (PV)}

Fish oil quality level is determined by the PV. Peroxide is formed by the binding of oxygen into the double bonds found in unsaturated fatty acids. Gunawan et al. (2003) explained that oil that is in direct contact with air and high temperatures can result in the unsaturated fatty acids breaking down. The carbon chain in the double bond is broken, resulting in a free fatty acid and peroxide increase. Inadequate processing, handling, and an unstable extraction temperature of the fish oil results in a high $\mathrm{PV}$, as well as accelerating oxidation.The smaller the PV, the better the quality of the oil (Panagan et al., 2011). Factors that can cause a high PV include high temperatures and the type of clear packaging that will accelerate the oxidation process in the oil. Peroxide values that exceed the standard can cause the body to be poisoned if consumed (Ketaren, 2012). It accelerates the smell of rancidity and has an unliked flavor, and it is toxic to the body if the peroxide value is more than $100 \mathrm{meq} / \mathrm{Kg}$ (Nurhasnawati et al., 2015). The increase of the peroxide number indicates a rise in peroxide that causes damage to the oil and gives off foul odor.

Before adding activated carbon, the peroxide value of the lemuru fish oil was determined to be 42 $\mathrm{meq} / \mathrm{Kg}$ as shown in Figure 2. The peroxide value was high while the limit required for the peroxide value by the IFOS (2014) is $\mathrm{PV} \leq 5 \mathrm{meq} / \mathrm{Kg}$ (IFOS, 2014). The oxidation process of the oxygen in the air can be the contributing factor in the alteration of the unsaturated fatty acids, as it decays the oil or fat (Panagan et al., 2011). Unsaturated fatty acids are significantly reactive to oxygen, increasing the number of double bonds in the molecular chain. The spontaneous oxidation of bland fatty acids is based on the intervention of oxygen in the double bonds to form peroxides (Panagan et al., 2011).

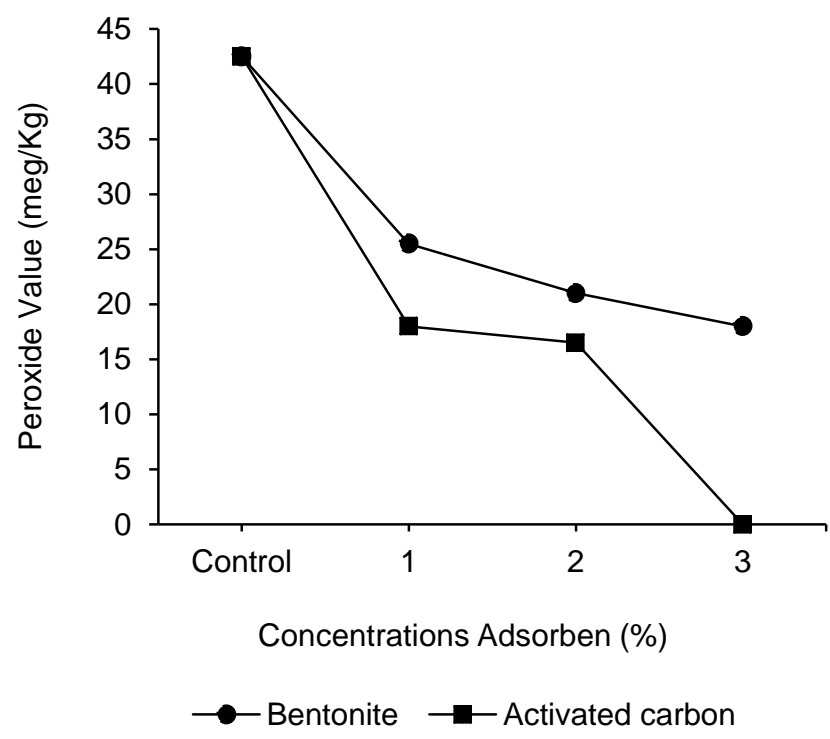

Figure 2. Peroxide value of the lemuru fish oil treated with bentonite and activated carbon

The PV was evaluated by comparing the lemuru fish oil with and without the addition of 1,2 and $3 \%$ activated carbon and bentonite. As shown in Figure 2, the addition of activated carbon to the lemuru fish oil is more effective than bentonite at decreasing the PV because activated carbon has a large surface area and pores that allow it to bind and adsorb more peroxide compounds in the oil (Miskah et al., 2019). This result indicates that activated carbon played a significant role in decreasing the PV from 42.5 to $0 \mathrm{meq} / \mathrm{Kg}$. This was highly accurate compared to the PV testing of $58.38 \mathrm{meq} / \mathrm{Kg}$ found in the previous study (Nadia et al., 2020).

The initial characterization data of the lemuru fish oil sample showed that the concentration of FFA and the peroxide number were under the safe limits to be consumed based on commercial fish oil standard by the IFOS. This means that the purifica- 
tion process carried out played a significant role in reducing the FFA content and PV.

\section{Clarity}

The clarity level of the fish oil was presented in the form of light absorbance as shown on the spectrophotometer. Measurements were made at a wavelength of $440 \mathrm{~nm}$. The highest clarity level obtained from $3 \%$ activated carbon was able to reduce the absorbance from 0.883 to 0.559 as shown in Figure 3. This is close to the clarity of commercial fish oils. Through this treatment, the color of lemuru fish oil changed from opaque to slightly yellow.

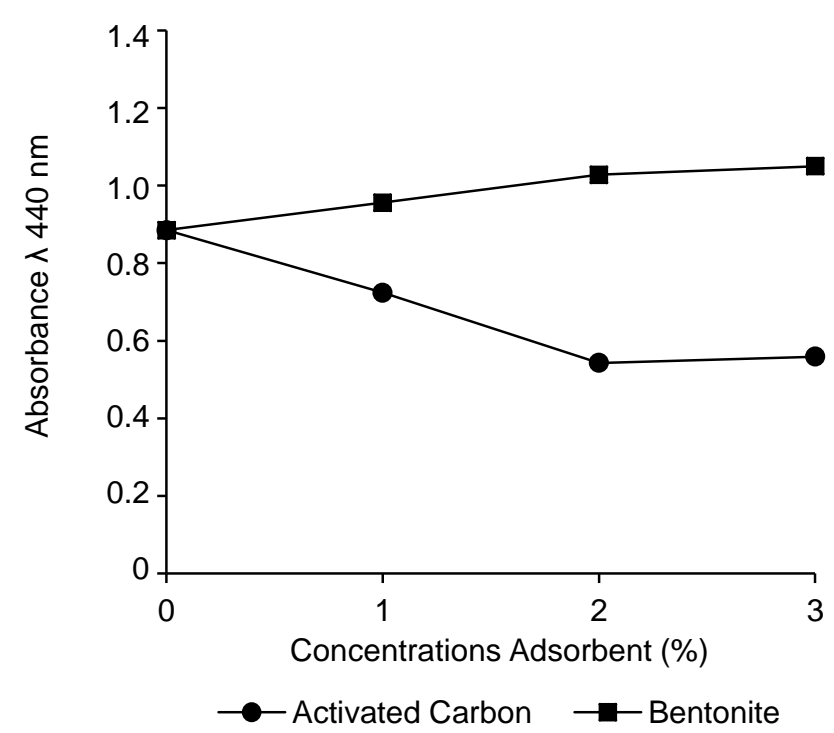

Figure 3. Clarity of the lemuru fish oil

Activated carbon played a significant role due to absorbing the color of the fish oil through its pores. Primary and secondary oxidation products tend to affect the color and turbidity of fish oil. The higher the amount of primary and secondary oxidation products, the darker the color, and the more the clarity is decreased. The presence of impurities such as slime, sap and gum in fish oil will result in a higher level of absorbance.

\section{Omega-3 analysis}

Pertaining to the saturation of carbon, the separation of the fatty acids can be accomplished using adsorbents. HPLC and silver resin chromatography have been employed for the preparation of omega-3 concentrates (Shahidi and Wanasundara, 1998). Analytical gas-liquid chromatography enables the excellent separation of polyunsaturated fatty acid esters but it is difficult to scale up. In this study, the omega-3 fatty acid analysis was performed using GC-FID. All peaks provided an excellent resolution, as shown by the distinct separation of the base peaks. In relation to this result, the analysis of the omega-3 was performed using an HP-5 capillary column paired with the GC-FID.

The linearity of the omega-3 determination using GC-FID was investigated, and the results are presented in Table 1. For all omega-3 tests, the linear range was 0 to $2000 \mu \mathrm{g} / \mathrm{mL}$ at a correlation coefficient of $\geq 0.999$. Figure 4 shows the chromatogram of lemuru fish oil following the hydrolysis process using lipase, which results in the presence of $\alpha$-linolenic acid, eicosapentaenoic acid and docosahexaenoic acid. The chromatogram reveals that the HP-5 capillary column was selective when it came to separating out the components in the lemuru fish oil.

\section{The effect of enzyme concentration on the omega-3 content}

The omega-3 content obtained from fish oil treatments was enriched through an enzymatic reaction using lipase to improve the quality of the lemuru fish oil. The enzyme concentration and incubation time were evaluated. The enzymatic hydrolysis of lemuru fish oil was carried out by evaluating the effects of enzyme concentration and the incubation process time on the omega- 3 content. The optimum enzyme concentration in the enzymatic hydrolysis process is shown in Figure 5 . The increase in enzyme concentration accelerated the reaction with the function of getting the available substrates to bind. After all of the substrates were bound, the reaction was no longer accelerated because there was no more binding to the additional enzymes. The optimum enzyme concentration was found by varying the enzyme concentration to produce a high omega- 3 content. Figure 5 presents the optimal amount of enzyme for 1000 units $/ \mathrm{g}$ of fish oil with which to obtain ALA, EPA, and DHA with concentrations of $0.870,2.56$, and $0.30 \%$ respectively. This was a more efficient analysis compared to the enzyme concentration of 20,000 units/g found in the previous study (Nugrahini et al., 2016).

Table 1. Calibration curve data of the omega-3 fatty acid standards

\begin{tabular}{lcccc}
\hline \multirow{2}{*}{ Compound } & \multirow{2}{*}{$\mathrm{tR}(\mathrm{min})$} & \multirow{2}{*}{ Linear Range $(\mu \mathrm{g} / \mathrm{mL})$} & \multicolumn{2}{c}{ Calibration Data } \\
\cline { 3 - 5 } & & $0-2000$ & Correlation Coefficient $(\mathrm{R})$ & Equation \\
\hline ALA & 14.001 & $0-2000$ & 0.999 & $\mathrm{y}=1.102+0.142 \mathrm{x}$ \\
EPA & 15.431 & $0-2000$ & 0.999 & $\mathrm{y}=0.391+0.036 \mathrm{x}$ \\
DHA & 16.947 & & 0.999 & $\mathrm{y}=1.628+0.139 \mathrm{x}$ \\
\hline
\end{tabular}




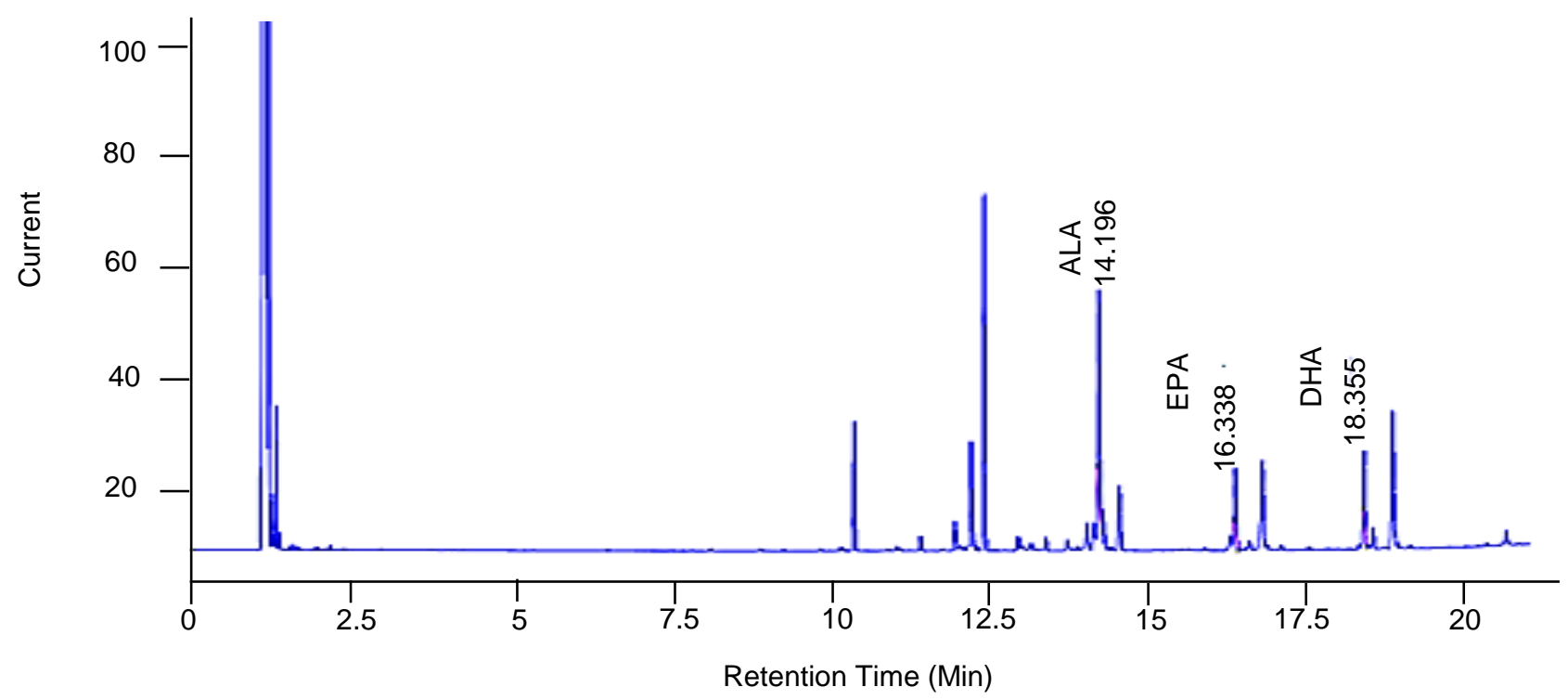

Figure 4. Representative chromatogram of lemuru fish oil fatty acids

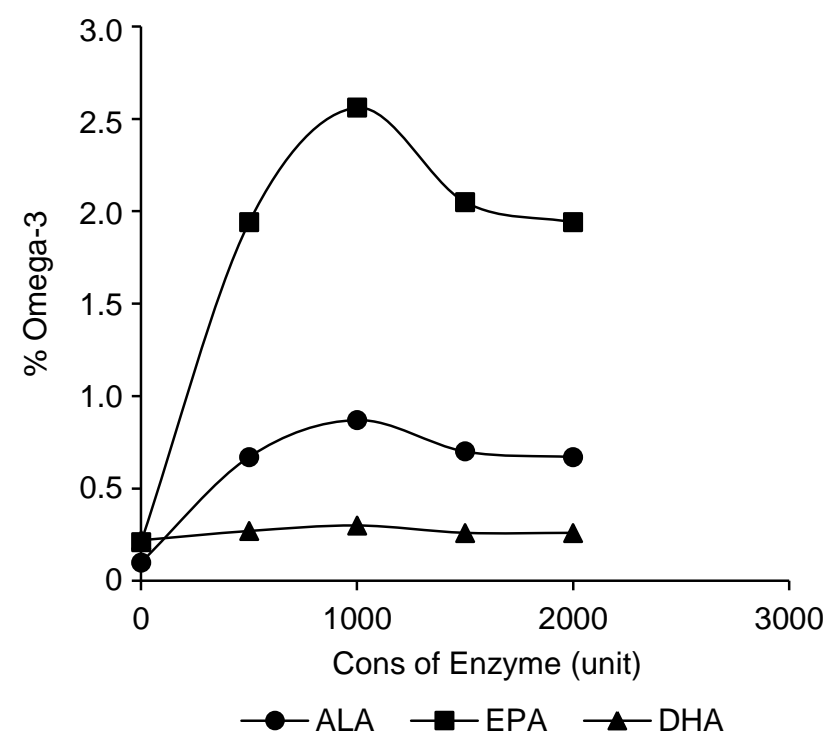

Figure 5. Effect of enzyme concentration on the omega 3 content of lemuru fish oil

\section{The effect of incubation time on the omega-3 content}

The enzymatic reaction time is a priority for products since a long enzymatic reaction might be detrimental. The enzymatic reaction must be controlled due to the reversible enzymatic reaction potential. The optimum incubation time was found by varying the incubation time to produce a high omega-3 content. Figure 6 explains that the highest ALA, EPA and DHA content was reached after 35 hours incubation time with a concentration of 0.78 , 1.06 , and $0.29 \%$ respectively, which shows a faster analysis outcome compared to the incubation time of 40 hours found in the previous study (Wanasundara and Shahidi, 1998).

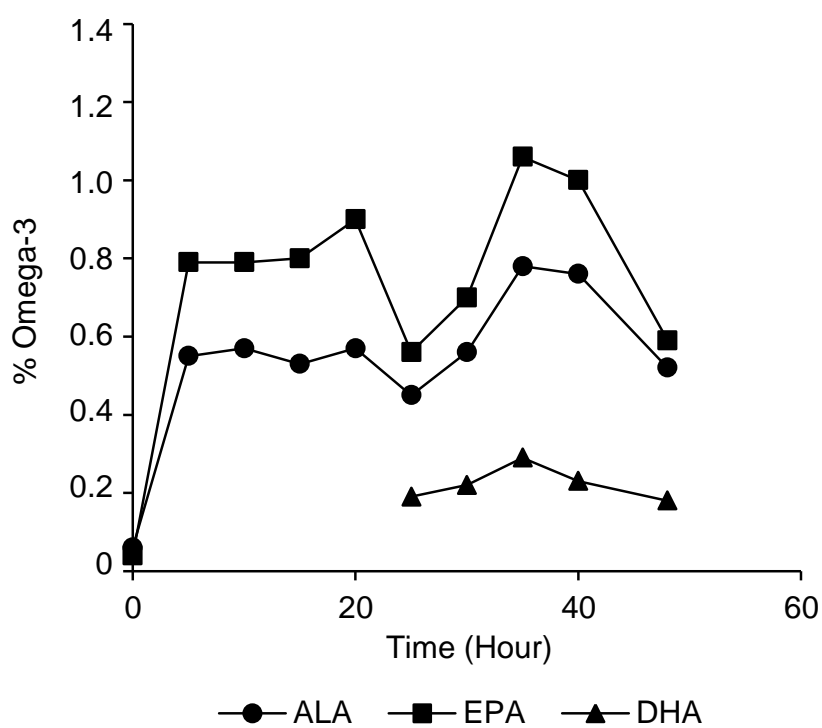

Figure 6. Effect of incubation time on the omega 3 content of lemuru fish oil

\section{CONCLUSION}

The results obtained in this study show that the combination of $3 \%$ activated carbon and 3\% bentonite as an adsorbent allows for the purification of lemuru fish oil to improve its quality. The proposed procedure is rapid, easy and inexpensive, decreasing the FFA content and PV, thus improving the clarity of the lemuru fish oil. GC analysis also shows that the oil with the highest omega-3 (ALA, EPA and DHA) content was obtained using hydrolysis with lipase at a concentration of 1000 units for 35 hours. As the result, the omega- 3 fatty acid content of lemuru fish oil can be increased tenfold. 
This technique provides an accurate result and can improve the quality of lemuru fish oil. The results of the analysis provide a tolerance value that is within the standard limit of IFOS.

\section{ACKNOWLEDGMENT}

The authors would like to thank INSINAS Ristekdikti for financially supporting this research. The authors would also like to thank the Research Unit for Clean Technology LIPI for providing the laboratory facilities.

\section{REFERENCES}

Abdulrashed RAG, Chandrashekariah AS. 2014. Omega fatty acids in health and disease - a review. J Pharm Res 8: 1027-1044.

Abu-Ouf NM, Jan MM. 2014. The influence of fish oil on neurological development and function. Can J Neurol Sci 41: 13-18. DOI: 10.1017/S031716 710001619X.

Ahmed R, Haq M, Cho YJ, Chun BS. 2017. Quality evaluation of oil recovered from by-products of bigeye tuna using supercritical carbon dioxide extraction. Turk J Fish Aquat Sci 17: 663-672. DOI: 10.4194/1303-2712-v17_4_02.

Akbar U, Yang M, Kurian D, Mohan C. 2017. Omega-3 Fatty acids in rheumatic diseases. JCR: J Clin Rheumatol 23: 330-339. DOI: 10.10 97/rhu.0000000000000563.

[AOAC] Association of Official Analytical Chemist. 2005. Determination of peroxide value. 4th edition. AOAC International Suite 500. 481 North Frederick Avenue Gaithersburg, Maryland 20877-2417, USA.

Aryani T, Utami F, Sulistyaningsih. 2017. Identifikasi asam lemak omega pada ASI eksklusif menggunakan kromatografi GC-MS. J Health Stud 1: 1-7.

Ayu BIG, Soni H, Gofar IE. 2020. Characteristics of fish oil produced through madidihang fishmeal industry waste treatment (Thunnus Albacares) using adsorbents. RJOAS 3: 69-76. DOI: 10. 18551/rjoas.2020-03.08.

Azman AN, Sumanto, Edison. 2018. Extraction and characteristics of catfish (Paraplotosus albilabris) oil with different solvent. Berkala Perikanan Terubuk 46: 19-27.

Bija S, Suseno SH, Uju. 2016. Pemurnian minyak ikan sardin dengan tahapan degumming dan netralisasi. J Pengolah Hasil Perikan Indones 20: 143-152.
Billman GE, Harris W. 2011. Effect of dietary omega-3 fatty acids on the heart rate and the heart rate variability responses to myocardial ischemia or submaximal exercise. Am J Physiol Heart Circ Phyciol 300: H2288-H2299. DOI: 10.1152/ajpheart.00140.2011.

Bonilla JR, Concha JLH. 2018. Methods of extraction, refining and concentration of fish oil as a source of omega- 3 fatty acids. Ciencia y Tech Agropecuaria 19: 645-668. DOI: 10.2193 0/rcta. vol19_num2_art:684.

[BPS] Badan Pusat Statistika. 2015. Ekspor-impor Minyak Ikan: Badan Pusat Statistika https:// www.bps.go.id/subject/56/perikanan.html [April $\left.29^{\text {th }} 2016\right]$.

Calvo MH, Martínez MS, Torres W, Castillo MC, Luzardo E, Villasmil N, Salazar J, Velasco M, Bermúdez V. 2017. Omega-3 polyunsaturated fatty acids and cardiovascular health: A molecular view into structure and function. Vessel Plus 1: 116-128.

Charanyaa S, Belur PD, Regupathi I. 2017. A New strategy to refine crude Indian sardine oil. J Oleo Sci 66: 425-434. DOI: 10.5650/jos.ess 16 164.

Dari DW, Astawan M, Wulandari N, Suseno SH. 2017. Karakterisasi minyak ikan sardin (Sardinella sp.) hasil pemurnian bertingkat. J Pengolah Hasil Perikan Indones 20: 456-467. DOI: 10.17844/jphpi.v20i3.19766.

Dinicolantonio JJ, Niazi AK, McCarty MF, O'Keefe $\mathrm{JH}$, Meier P, Lavie CJ. 2014. Omega-3s and cardiovascular health. Ochsner J 14: 399-412.

Elagizi A, Lavie C, O'Keefe E, Marshall K, O'Keefe J, Milani R. 2021. An update on omega-3 polyunsaturated fatty acids and cardiovascular health. Nutrient 204: 1-12.

Eltweri AM, Thomas AL, Metcalfe M, Calder PC, Dennison AR, Bowrey DJ. 2017. Potential applications of fish oils rich in omega- 3 polyunsaturated fatty acids in the management of gastrointestinal cancer. Clin Nutr 36: 65-78. DOI: 10. 1016/j.clnu.2016.01.007.

Endo J, Arita M. 2016. Cardioprotective mechanism of omega-3 polyunsaturated fatty acids. J Cardiol 67: 22-27. DOI: 10.1016/j.jjcc.2015.08. 002.

Ferrari R, Censi S, Cimaglia P. 2020. The journey of omega-3 fatty acids in cardiovascular medicine. Eur Heart J 22: J49-J53. DOI: 10.1093/ eurheartj/suaa118.

Fonda G, Pranata R, Deka H. 2016. Role of omega3 fatty acids in dyslipidemia and cardiovascular diseases. Indonesian J Cardiol 37: 1-6. DOI: 10.30701/ijc.v37i4.586. 
Francis FJ. 1999. Wiley Encyclopedia of Food Science and Technology, $2^{\text {nd }}$ Editions. 737-738. John Wiley and Sons, USA.

García-Moreno PJ, Guadix A, Gómez-Robledo L, Melgosa M, Guadix EM. 2013. Optimization of bleaching conditions for sardine oil. J Food Eng 116: 606-612. DOI: 10.1016/j.jfoodeng.2012.12. 040.

Ghani AF. 2014. Purification of Sardinian Fish Oil (Sardinella sp.) Using Active Charcoal and Bleaching Earth [Skripsi] Bogor: Faculty of Fisheries and Marine Science, Bogor Agricultural Institute.

Harris W, Tintle N, Etherton M, Vasan R. 2018. Erythrocyte long-chain omega-3 fatty acid levels are inversely associated with mortality and with incident cardiovascular disease: The Framingham Heart Study. J Clin Lipidol 12: 718-727. DOI: 10.1016/j.jacl.2018.02.010.

Haryati K, Suseno SH, Nurjanah. 2017. Minyak ikan sardin hasil sentrifugasi dan adsorben untuk emulsi. J Pengolah Hasil Perikan Indones 20: 84-94. DOI: 10.17844/jphpi.v20i1.16437.

Hong MY, Lumibao J, Mistry P, Saleh R, Hoh E. 2015. Fish oil contaminated with persistent organic pollutants reduces antioxidant capacity and induces oxidative stress without affecting its capacity to lower lipid concentrations and systemic inflammation in rats. J Nutr 145: 939944. DOI: 10.3945/jn.114.206607 .

Hu Y, Hu FB, Manson JE. 2019. Marine omega-3 supplementation and cardiovascular disease: an updated meta-analysis of 13 randomized controlled trials involving 127477 participants. J Am Heart Assoc 8: 1-6. DOI: 10.1161/JAHA. 119.013543.

[IFOS] International Fish Oil Standard. 2014. Fish Oil Purity Standars. www.Omegavia.com/best

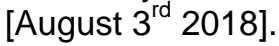

Jo S-H, Han SH, Kim S-H, Eckel RH, Koh KK. 2021. Cardiovascular effects of omega-3 fatty acids: Hope or hype?. Atherosclerosis 322: 15-23. DOI: 10.1016/j.atherosclerosis.2021.02.014.

Jump DB, Depner CM, Tripathy S. 2012. Omega-3 fatty acid supplementation and cardiovascular disease. J Lipid Res 53: 2525-2545. DOI: 10.1194/jlr.R027904.

Ketaren S. 2012. Pengantar Teknologi Minyak dan Lemak Pangan. 1-7. UI Press, Depok.

Kolanowski W. 2010. Omega-3 LC PUFA contents and oxidative stability of encapsulated fish oil dietary supplements. Int J Food Prop 13: 498511. DOI: $10.1080 / 10942910802652222$
Kones R, Rumana U. 2017. Omega-3 polyunsaturated fatty acids: New evidence supports cardiovascular benefits. J Public Health Emerg 1: 1-4. DOI: 10.21037/jphe.2017.03.04.

Kralovec J A, Zhang S, Zhang W, Barrow CJ. 2012. $A$ review of the progress in enzymatic concentration and microencapsulation of omega-3 rich oil from fish and microbial sources. Food Chem 131: 639-644. DOI: 10.1016/j.foodchem. 2011.08.085.

Kromhout D, Yasuda S, Geleijnse JM, Shimokawa H. 2012. Fish oil and omega-3 fatty acids in cardiovascular disease: Do they really work?. Eur Heart J 33: 436-443. DOI: 10.1093/eur heartj/ehr362.

Lombardi M, Carbone S, Buono MG, Chiabrando JG, Vescovo GM, Camili M, Montone RA, Vergallo R, Abbate A, Zoccai G, Dixon D, Crea F. 2021. Omega-3 fatty acids supplementation and risk of atrial fibrillation: An updated metaanalysis of randomized controlled trials. Eur Heart J Cardiovasc Pharmacot 8: 1-2. DOI: 10.1093/ehjcvp/pvab008.

Maes J, Meulenaer B, Heerswynghels P, Greyt W, Eppe G, Pauw E, Huyghebaert A. 2005. Removal of dioxins and PCB from fish oil by activated carbon and its influence on the nutritional quality of the oil. J Am Oil Chem Soc 82: 593597. DOI: 10.1007/s11746-005-1114-1.

Maki KC, Palacios OM, Bell M, Toth PP. 2017. Use of supplemental long-chain omega-3 fatty acids and risk for cardiac death: An updated metaanalysis and review of research gaps. J Clin Lipidol 11: 1152-1160. DOI: 10.1016/j.jacl. 2017.07.010.

Manson JE, Cook NR, Lee I-M, Christen W, Bassuk SS, Mora S, Buring JE. 2018. Marine n-3 fatty acids and prevention of cardiovascular disease and cancer. N Engl J Med 380: 23-32. DOI: 10.1056/nejmoa1811403.

Minihane AM. 2013. Fish oil omega-3 fatty acids and cardio-metabolic health, alone or with statins. Eur J Clin Nutr 67: 536-540. DOI: 10.1038/ ejcn.2013.19.

Miskah S, Aprianti T, Agustien M, Utama Y, Said M. 2019. Purification of used cooking oil using activated carbon adsorbent from durian peel. IOP Conf Ser: Earth Environ Sci 396: 1-7. The 2nd International Conference on Smart City Innovation, October 9th 2019, Semarang, Indonesia.

Mohebi NA, Bikdeli B. 2014. Omega-3 supplement and cardiovaskuler diseases. Tanaffos 13: 614. 
Monte ML, Monte ML, Pohndorf RS, Crexi VT, Pinto LAA. 2015. Bleaching with blends of bleaching earth and activated carbon reduces color and oxidation products of carp oil. Eur J Lipid Sci Tech 117: 829-836. DOI: 10.1002/ejlt.2014 00223.

Mori TA. 2014. Omega-3 fatty acids and cardiovascular disease: Epidemiology and effects on cardiometabolic risk factors. J Food Funct 5: 2000-2019. DOI: 10.1039/c4fo00393d.

Mozaffarian D, Wu JHY. 2011. Omega-3 fatty acid and cardiovascular disease: Effect on risk factors, molecular pathways, and clinical events. J Am Coll Cardiol 58: 2047-2067. DOI: 10.1016/j.jacc.2011.06.063.

Nadia A, Subekti S, Manan A, Wahyudin P. 2020. The effectiveness of activated carbon as adsorbent in the oil purification process fish byproduct of the fish canning industry. IOP Conf Ser: Earth Environ Sci 441: 1-7. 2nd International Conference on Fisheries and Marine Science, September $26^{\text {th }} 2019$ Surabaya, Indonesia.

Nestel $\mathrm{P}$, Clifton $\mathrm{P}$, Colquhoun D, Noakes M, Mori TA, Sullivan D, Thomas B. 2015. Indications for omega-3 long chain polyunsaturated fatty acid in the prevention and treatment of cardiovascular disease. J Heart Lung Circ 24: 769-779. DOI: 10.1016/j.hlc.2015.03.020.

Nugrahini P, Sitompul H, Putra RD. 2016. Pengaruh waktu dan konsentrasi enzim selulase pada proses hidrolisis tandan kosong kelapa sawit menjadi glukosa. Anal Environ Chem 1: 8-16.

Nurhasnawati $H$, Supriningrum $R$, Caesariani $N$. 2015. Penetapan kadar asam lemak bebas dan bilangan peroksida pada minyak goreng yang digunakan pedagang gorengan di Jalan A W Sjahranie Samarinda. J Ilmiah Manuntung 1: 25-30.

Nurjanah, Suseno SH, Arifianto TB. 2014. Ekstraksi dan karakterisasi minyak dari kulit ikan patin (Pangasius hypophthalmus). Depik 3: 250-262.

Ostadrahimi A, Mohammad-Alizadeh S, Mirgafourvand M, Yaghoubi S, Shahrisa E, Farshbaf KA. 2016. Effects of fish oil supplementation on gestational diabetes mellitus (GDM): A Systematic Review. Iran Red Crescent Med J 18: 110. DOI: $10.5812 /$ ircmj.24690.

Panagan AT, Heni Y, Gultom JU. 2011. Analisis kualitatif dan kuantitatif asam lemak tak jenuh omega-3 dari minyak ikan patin (Pangasius pangasius) dengan metoda kromatografi gas. J Penelitian Sains 14: 14409.
Panagan AT, Yohandini H, Wulandari M. 2012. Analisis kualitatif dan kuantitatif asam lemak tak jenuh omega-3, omega-6 dan karakterisasi minyak ikan patin (Pangasius pangasius). J Penelitian Sains 15: 102-106.

Pereira ÉR, Kopp JF, Raab A, Krupp EM, Menoyo JDC, Carasek E, Welz, Feldmann J. 2016. Arsenic containing medium and long chain fatty acids in marine fish oil identified as degradation products using reversed-phase HPLC-ICPMS/ESI-MS. J Anal At Spectrom 31: 18361845. DOI: 10.1039/c6ja00162a.

Pirillo A, Catapano AL. 2013. Omega-3 polyunsaturated fatty acids in the treatment of hypertriglyceridaemia. Int J Cardiol 170: S16-S20. DOI: 10.1016/j.jijcard.2013.06.040.

Raharja S, Suryadarma P, Oktavia T. 2011. Hidrolisis enzimatik minyak ikan untuk poduksi asam lemak omega-3 menggunakan lipase dari Aspergillus Niger. J Teknol Industri Pangan 22: 64-72.

Raharja S, Suparno O, Mangunwidjaja D, Herdiyani A, Oktavia T, Najah Z. 2012. Penambahan pelarut organik pada media untuk hidrolisis enzimatik minyak ikan menggunakan lipase dari Aspergillus niger. J Teknol Industri Pertanian 22: 140-150.

Moharana TR, Byreddy AR, Puri M, Barrow C, Rao NM. 2016. Selective enrichment of omega-3 fatty acids in oils by phospholipase A1. PLoS One 11: 1-14. DOI: 10.1371/journal.pone.015 1370.

Rio D, Dwiputra $H$, Sudaryanto $\mathrm{Y}$, Indraswati $\mathrm{N}$. 2009. Bleaching vacuum minyak biji kapuk. Widya Teknik 8: 12-22.

Schuchardt J, Schneider I, Meyer H, Neubronner J, Schacky C, Hahn A. 2011. Incorporation of EPA and DHA into plasma phospholipids in response to different omega-3 fatty acid formulations - a comparative bioavailability study of fish oil vs. krill oil. Lipids Health Dis 10: 1-7.

Shahidi F, Wanasundara UN. 1998. Omega-3 fatty acid concentrates: Nutritional aspects and production technologies. Food Sci Technol 9: 230-240. DOI: 10.1016/S0924-2244(98)000442.

Siscovick DS, Barringer TA, Fretts AM, Wu JHY, Lichtenstein AH, Costello RB, Mozaffarian D. 2017. Omega-3 Polyunsaturated fatty acid (Fish Oil) supplementation and the prevention of clinical cardiovascular disease. Circ J 135: e867-e884. DOI: 10.1161/cir.0000000000000 482. 
Srigley CT, Rader JI. 2014. Content and composition of fatty acids in marine oil omega-3 supplements. J Agric Food Chem 62: 72687278. DOI: $10.1021 / \mathrm{j} 5016973$.

Stephenson JA, Al-Taan O, Arshad A, Morgan B, Metcalfe MS, Dennison AR. 2013. The multifaceted effects of omega-3 polyunsaturated fatty acids on the hallmarks of cancer. J Lipids 2013: 1-13. DOI: $10.1155 / 2013 / 261247$.

Suriani NW, Komansilan A. 2019. Enrichment of omega-3 fatty acids, waste oil by-products canning tuna (Thunnus $s p$.) with urea crystallization. J Phys: Conf Ser 1317: 1-6. DOI: 10.108 8/1742-6596/1317/1/012056.

Suseno SH, Izaki AF, Suptijah P, Jacoeb AM, Saraswati. 2013. Kinetic study of free fatty acid adsorption using adsorbent in sardine (Sardinella sp.) oil refining. Asian J Agric Food Sci 01: 286-293.

Wanasundara UN, Shahidi F. 1998. Lipase-assisted concentration of $n-3$ polyunsaturated fatty acids in acylglycerols from marine oils. J Am Oil Chem Soc 75: 945-951. DOI: 10.1007/s11746998-0271-9.
Weinberg RL, Brook RD, Rubenfire M, Eagle KA. 2021. Cardiovascular impact of nutritional supplementation with omega-3 fatty acids: JACC Focus Seminar. J Am Coll Cardiol 77: 593-608. DOI: 10.1016/j.jacc.2020.11.060.

Wen YT, Dai JH, Gao Q. 2014. Effects of Omega-3 fatty acid on major cardiovascular events and mortality in patients with coronary heart disease: A meta-analysis of randomized controlled trials. Nutr Metab Cardiovasc Dis 24: 470-475. DOI: 10.1016/j.numecd.2013.12.004.

Yang Z-H, Amar M, Sampson M, Courville AB, Sorokin AV, Gordon SM, Remaley AT. 2020. Comparison of Omega-3 eicosapentaenoic acid versus docosahexaenoic acid-rich fish oil supplementation on plasma lipids and lipoproteins in normolipidemic adults. J Nutr 12: 749. DOI: 10.3390/nu12030749.

Yinko SL, Stark KD, Thanassoulis G, Pilote L. 2014. Fish consumption and acute coronary syndrome - a meta-analysis. Am J Med 127: 848857. 